\title{
At-sea abundance and distribution of skuas and jaegers (Charadriiformes: Stercorariidae) at coastal waters off central Chile
}

\author{
Alejandro Simeone ${ }^{1 *}$, Cristóbal Anguita ${ }^{1}$ and Guillermo Luna-Jorquera ${ }^{2,3}$
}

\begin{abstract}
Background: Skuas and jaegers (Charadriiformes: Stercorariidae) are seabirds breeding at moderate to high latitudes and some perform extensive post-breeding transequatorial migrations. Most species overwinter and perform significant portions of their migratory flyways along the Pacific coast of South America, but scant information is available on their at-sea ecology in this waters. Our aims in this study were to determine: 1) the timing of occurrence and fluctuations in abundance of skua and jaeger species, 2) their spatial distribution within the coastal zone and 3) at-sea behavior of birds, including flock size and interactions with other seabird species.

Results: Between July 2006 and October 2013, we conducted at-sea bird counts at Valparaiso Bay (335) in central Chile and confirmed the occurrence of Chilean skuas (Stercorarius chilensis), Brown skuas (S. antarcticus), and Parasitic jaegers (S. parasiticus). Parasitic jaegers are regular austral summer visitors (November to March), whereas Brown skuas occur in the area only in winter (July to October). Chilean skuas were regularly recorded year-round in the area with higher abundances between late winter and early spring (August to October). Brown and Chilean skuas where observed comparatively offshore, whereas Jaegers presented a more coastal distribution, probably associated to host presence. Chilean skuas kleptoparasitized similar-sized (shearwaters and fulmars) and larger seabird species (boobies), whereas jaegers chased only smaller coastal birds (gulls and terns). Brown skuas engaged in no kleptoparasitic behaviors. All three species were observed mostly as solitary individuals.
\end{abstract}

Conclusions: Skuas and jaegers showed in general a marked seasonality in their occurrence and abundance (only Chilean skua occurs year-round) and use this area as a commuting and stopover zone within their extensive migratory flyway along the southeastern Pacific.

Keywords: Skuas; Jaegers; Stercorariidae; Seabirds; Kleptoparasitism; At-sea distribution

\section{Background}

The Stercorariidae constitutes a small, distinctive family of seven kleptoparasitic seabird species all now regarded as within the genus Stercorarius (Remsen et al. 2013), although much debate exists about their systematics; sometimes, more species and a second genus are recognized within the family (Cohen et al. 1997; Braun and Brufield 1998; Ritz et al. 2008; Chu et al. 2009). The family comprises the larger and mostly Brown skuas and the smaller, more agile jaegers. All breed at moderate to high latitudes and perform extensive post-breeding transequatorial

\footnotetext{
* Correspondence: asimeone@unab.cl

${ }^{1}$ Departamento de Ecología y Biodiversidad, Facultad de Ecología y Recursos Naturales, Universidad Andres Bello, República 470, Santiago 8370251, Chile Full list of author information is available at the end of the article
}

migrations (Furness 1987a). Species present in South America include the Brown (S. antarcticus Mathews) and the South Polar skuas (S. maccormicki Saunders) breeding in Antarctica and subantarctic islands. The Chilean skua (S. chilensis Bonaparte) confined to the fjords and coastal islands of Chile and Argentina (Harrison 1988; Yorio 2005). The Pomarine (S. pomarinus Temminck), Parasitic (S. parasiticus Linnaeus) and Longtailed jaegers (S. longicaudus Vieillot) breed in the Arctic tundra (Furness 1987a; Harrison 1988).

Skuas and jaegers are marine top predators and exert significant effects on their prey/host populations (Furness 1987a, b). Studies on these species have focused mainly on breeding ecology, kleptoparasitic behavior, and systematics. Contrastingly, comparatively less is known about their 
movements, marine habitat use, and at-sea behavior, particularly along the Pacific coast of South America where some species overwinter and perform significant portions of their migratory flyways (Phillips et al. 2007, 2009; Kopp et al. 2011). Recent studies have shown that South Polar skuas from Antarctica migrate to wintering areas into both northern Atlantic and northern Pacific (Kopp et al. 2011), and Brown skuas from South Georgia and Falklands overwinter in the Atlantic within the Argentine Basin between $37^{\circ}$ to $52^{\circ} \mathrm{S}$ (Phillips et al. 2007, 2009). Flyways and winter grounds of Brown skuas from Antarctica remain largely unknown and may include areas in the Atlantic and Pacific (Watson 1975; Furness 1987a; Jaramillo 2005; Raimilla 2012). Extent and timing of migration of the Chilean skua are largely unknown (Harrison 1988), although it has been reported as far north as the Peruvian coast, where it is considered a rare visitor (Harrison 1988; Schulenberg et al. 2010). After breeding during northern summer, all tundra species conduct extensive transequatorial migrations down to South American waters, both in the Atlantic and Pacific Oceans (Furness 1987a), but details on their movements and timing of migration remain largely unknown.

In 2006, we started an at-sea monitoring program of seabirds off the coast of Valparaiso in central Chile $\left(33^{\circ} \mathrm{S}\right)$, within the Humboldt Current System. This area is part of an extensive flyway for several boreal and austral migratory species (Spear and Ainley 2008) and supports a high marine productivity derived from intense upwelling (Thiel et al. 2007; Aiken et al. 2008), which in turn, sustains large numbers of endemic, resident, and migratory seabird species (Spear and Ainley 2008). Our aims in this study were to determine: (1) the timing of occurrence and fluctuations in abundance of skua and jaeger species, (2) their spatial distribution within the coastal zone, and (3) at-sea behavior of birds, including flock size and interactions with other seabird species.

\section{Methods}

\section{Data collection}

From July 2006 throughout October 2013, we performed monthly counts of seabirds within the Valparaiso Bay $\left(32^{\circ} 56^{\prime}\right.$ to $33^{\circ} 01^{\prime} \mathrm{S}, 71^{\circ} 36^{\prime}$ to $\left.71^{\circ} 46^{\prime} \mathrm{W}\right)$ in central Chile, encompassing a maximum area of $c a 110 \mathrm{~km}^{2}$ (Figure 1). The counts were performed using $10 \times 42$ binoculars from a 10-m long motor vessel (120 HP) usually between 1030 and 1330 hours using a standard method for counting seabirds at sea (Tasker et al. 1984; Webb and Durinck 1992; Garthe and Hüppop 1996, 2000; Camphuysen and Garthe 2004). In this method, the birds are counted by two independent teams of two observers at each side of the boat along a line transect. Data recorded by each group of observers included the identity of the species (using a standardized coding after Camphuysen and Garthe 2004), abundance, flock size, distance to the boat, behavior

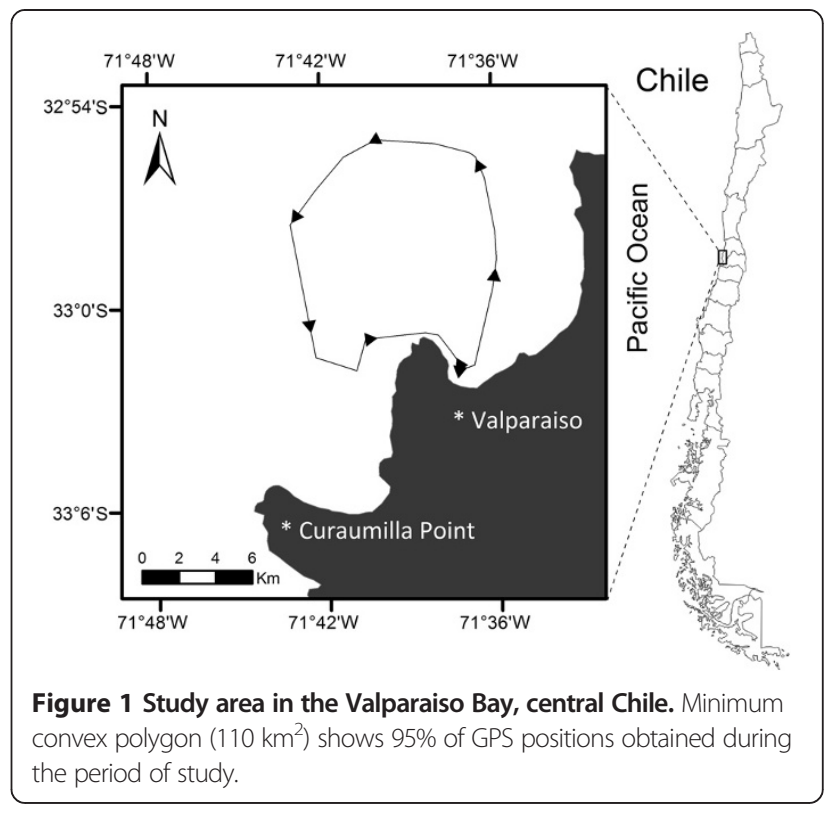

(feeding, resting, and kleptoparasitism), and flocking with conspecifics or other species.

For birds that are on the water, we counted them in transect' if they were within a 250-m-wide distance band perpendicular to the boat. This band was subdivided into three discrete bands: 0 to 50,50 to 100 , and 100 to $250 \mathrm{~m}$. The birds outside this area were considered as to be 'outside transect' and were not considered for density estimates (see below).

For birds that are flying, we considered 'snapshots' of the number of birds flying within a hypothetical box $250 \mathrm{~m}$ wide and ahead. This was performed at the beginning of each minute (second 0), and all flying birds within this area at second 0 were considered within transect. This convention greatly reduces overestimation in bird abundance (Tasker et al. 1984). The method assumes that target species behave independently of the ship, so ship followers were not recorded as animals in transect and were kept aside at all times (Camphuysen et al. 2004).

Transects extended up to $15 \mathrm{~km}$ offshore within the limits of the continental shelf, and the navigation speed was kept at constant as possible between 10 and $12 \mathrm{~km} / \mathrm{h}$, so as to obtain adequate detection of birds, particularly those on the water (Garthe and Hüppop 1999). As much as weather and wave conditions made possible, each month, we kept the same track and trip duration $(c a 3 \mathrm{~h})$. The counts were performed only if a minimal set of weather and sea conditions were present, including visibility $>1 \mathrm{~km}$ and sea state $\leq 5$ (Beaufort scale).

Bird abundance was expressed as density (individuals $/ \mathrm{km}^{2}$ ) to standardize for differential transect length performed each trip, and this was calculated by dividing the amount of birds counted in transect by a known surface area. The ship 
speed was kept at constant as possible at $10 \mathrm{~km} / \mathrm{h}$, and considering the transect width of $0.5 \mathrm{~km}(0.25 \mathrm{~km}$ at each side of the boat, see above), we covered $1 \mathrm{~km}^{2}$ every $12 \mathrm{~min}$.

The position and speed of the boat were recorded every 10 min using a GPS. The distance of the observed birds to the coast was estimated by using the nearest GPS position of the bird to the nearest coast section in a straight line. The measurements were made using ArcGIS v. 10 (Esri Chile S.A., Santiago, Chile). The names and systematics followed Remsen et al. (2013).

\section{Data analyses}

For each species, we determined the overall patterns of spatial distribution using fixed kernel (bivariate normal kernel) utilization distributions (UD) (Worton 1989, 1995), which provide a probability contour, indicating the relative proportion of the distribution within a particular area. Using this model, one can define kernel density contour as the minimum area in which an animal has some specified probability of being located (Calenge 2006). The smoothing parameter $(h)$ was estimated for each species using the ad hoc method proposed by Silverman (1986) as follows: S. chilensis $=1,653 \mathrm{~m}, S$. parasiticus $=1,397 \mathrm{~m}$, and $S$. antarcticus $=2,068 \mathrm{~m}$. For S. chilensis and S. parasiticus, the contour levels were estimated for $25 \%, 50 \%, 75 \%$, and $95 \%$ of the locations, and for S. antarcticus, the contour level were estimated only for $95 \%$ due to the limited number of recorded individuals.

Spatial analyses were performed using the package adehabitatHR (CRAN, Wirtschaftsuniversität Wien, Vienna, Austria) (Calenge 2006) in R. The values of distance presented high heteroscedasticity and did not fit to a normal distribution. We thus conducted permutational analyses of variance to examine whether the distance to the coast varied significantly across the skua species. Permutational $p$ values were calculated by using 1,000 permutations. The average probability of sighting a particular species at a particular month was calculated, applying a generalized linear model assuming a binomial error structure. The analyses were conducted in the $\mathrm{R}$ package (http://CRAN.R-project.org).

We used a multivariate analysis of variance (MANOVA) to compare the monthly abundances within each species. Because data were not normally distributed and variance was not homogeneous, we used Monte Carlo simulation to obtain a permutational $F$ value using 9,999 permutations.
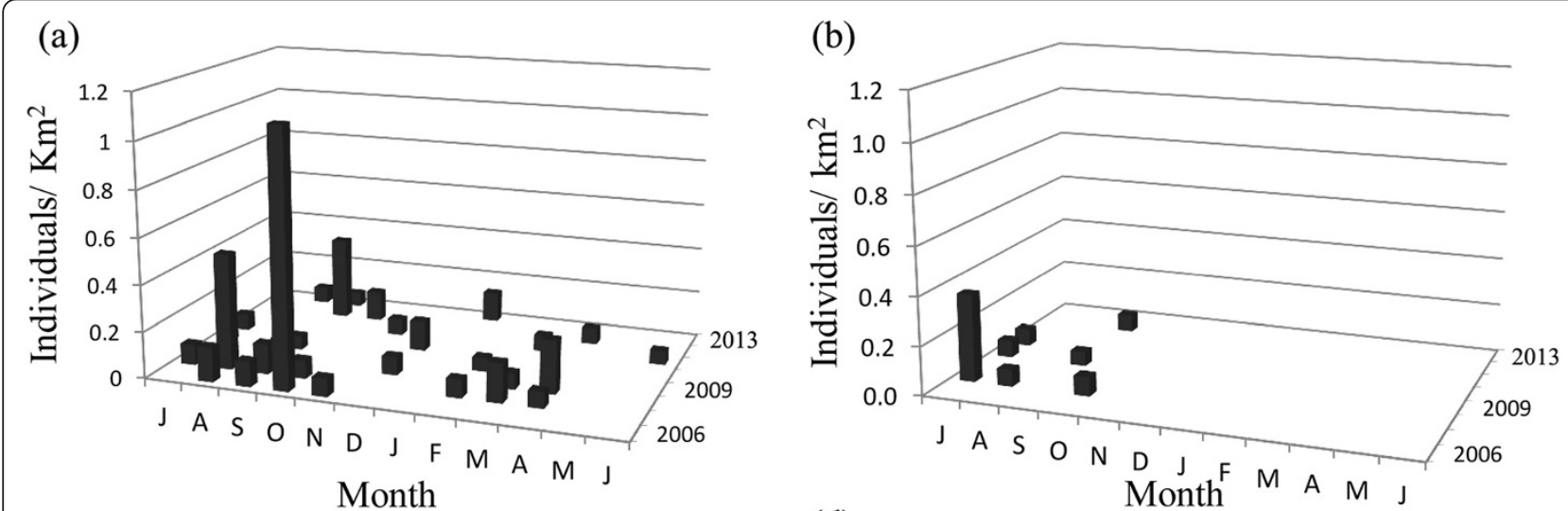

(c)

(d)
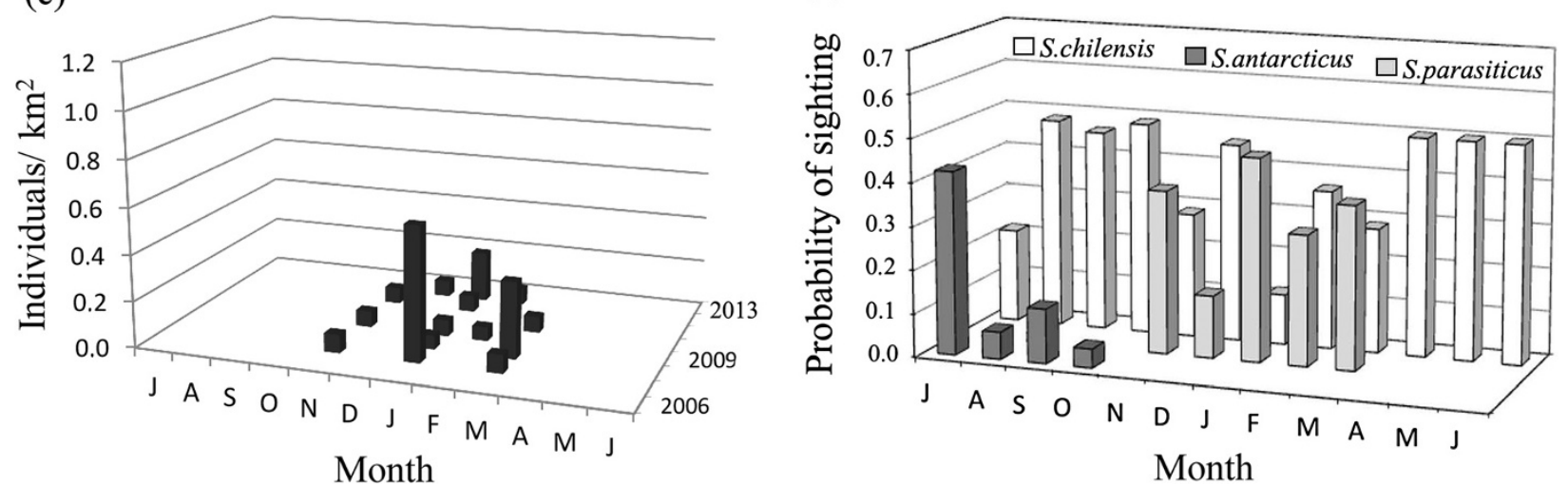

Figure 2 Monthly densities (individuals $/ \mathbf{k m}^{2}$ ) of skuas and jaegers between July 2006 and October 2013. (a) Stercorarius chilensis, (b) S. antarcticus, (c) S. parasiticus, and (d) probability of sighting a particular species in a particular month. 


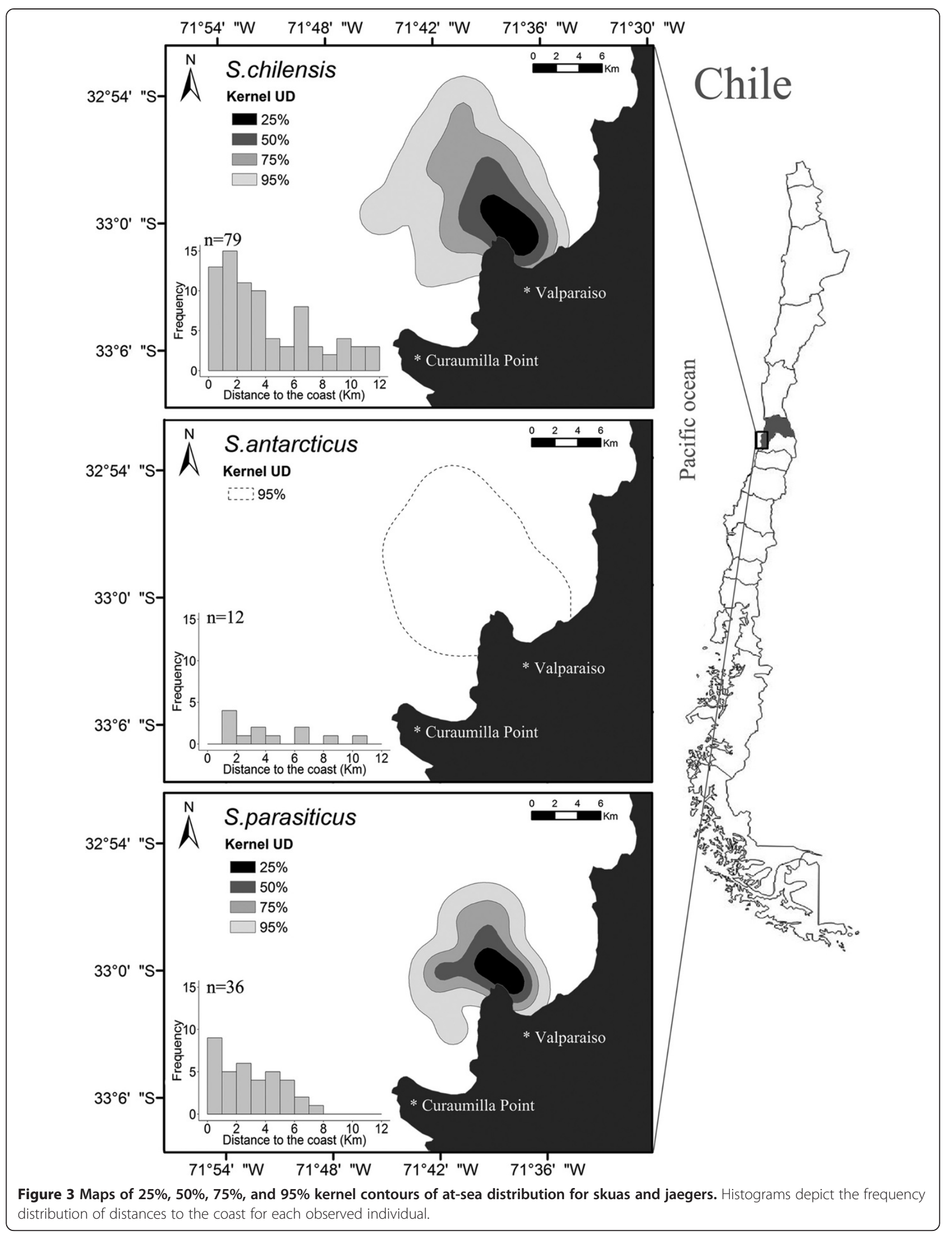




\section{Results}

Between July 2006 and October 2013, we recorded three Stercorarius species off Valparaiso (Figure 2): Chilean skua (65 records), Parasitic jaeger (28 records), and Brown skua (12 records). The Chilean skuas occurred regularly yearround in the study area, and there was a clear tendency in this species to increase in density between late winter and early spring (August to October, maximum observed density $=1.1$ individuals $/ \mathrm{km}^{2}$, Figure 2a). The Brown skuas were detected in the area mostly in winter between July and October and in low densities (maximum observed density $=0.36$ individuals $/ \mathrm{km}^{2}$, Figure 2b). Parasitic jaegers are regular summer visitors in the study area from November to March, with higher densities between January and March (maximum observed density $=0.58$ individual $/ \mathrm{km}^{2}$, Figure 2c). The results of the MANOVA indicates that the densities between the months of the year significantly differed from each other for the three species considered (Wilks's lambda $=0.746, P=0.0001$; Figure 2a, b, c). Similarly, univariate tests for each species confirmed highly significant differences between monthly abundances $(P<0.0001)$. The probabilities of observing each particular species at each particular month are presented in Figure 2d.

Parasitic jaegers occurred, on average, much closer to the coast (within the first $8 \mathrm{~km}$ ) than the two other skua species; Brown and Chilean skuas occurred at similar distances within the first 10 to $12 \mathrm{~km}$ from the coast (Figure 3, Table 1; $F_{2,102}=31.04, P<0.0001$ ).

In all three Stercorarius species, the individuals were most frequently observed as singletons (Figure 4), with up to three individuals in the Chilean skua and four in the Parasitic jaeger. All observed Brown skuas were single birds. Brown skuas were never seen associated to any other seabird species, whereas jaegers were associated to five species of gulls and terns exclusively for kleptoparasitic purposes (Table 2). Chilean skuas engaged in associations with nine seabird species for kleptoparasitic, feeding, and resting purposes (Table 2).

\section{Discussion}

All three recorded Stercorarius species were most likely commuting between breeding and wintering areas (or vice versa) as none has breeding grounds in the proximity of the study area: Chilean skuas breed in southern Chile and

Table 1 Mean and $95 \% \mathrm{Cl}$ of distances to the coastline reached by skuas and jaegers

\begin{tabular}{lcccc}
\hline & Mean & $\boldsymbol{L} \mathbf{9 5 \%} \mathbf{C l}$ & $\boldsymbol{U} \mathbf{9 5 \%} \mathbf{C l}$ & $\mathbf{n}$ \\
\hline Chilean skua & 4.28 & 3.48 & 5.08 & 79 \\
Brown skua & 4.18 & 2.55 & 5.80 & 12 \\
Parasitic jaeger & 2.87 & 2.09 & 3.65 & 36 \\
\hline
\end{tabular}

Sample size $(\mathrm{n})$ is number of sighted individuals. Statistics were obtained using 1000 permutations (see methods for details). All distances in $\mathrm{km} . \mathrm{Cl}$, confidence interval; $L$, lower confidence bound; $U$, upper confidence bound.
Argentina, Parasitic jaegers in the Arctic tundra, and Brown skuas in Antarctica, subantarctic islands, and Argentine Patagonia (Furness 1987a, b; Harrison 1988; Yorio 2005).

Wintering grounds of Parasitic jaegers and Chilean skuas are known to include waters off the southeastern Pacific including the coast of Peru and Chile within the Humboldt Current (Furness 1987a, b; Harrison 1988). The wintering grounds and migratory routes of Brown skuas, on the contrary, are less clear. Phillips et al. (2007) showed that Brown skuas from South Georgia and Falkland Islands (Atlantic) overwinter widely over deep, oceanic waters within the Argentine Basin $\left(37^{\circ}\right.$ to $\left.52^{\circ} \mathrm{S}\right)$ between the Antarctic Polar Front and the Northern Subtropical Front. Jaramillo (2005) states that the status of this species in the Pacific is unclear and suggests that wintering grounds extend only along the Atlantic coast. However, recent observations of Raimilla (2012) at the Diego Ramirez Archipelago suggest that the Pacific may also be part of the migratory flyway of this species. Our observations confirm that Brown skuas (most likely post-breeders from Antarctic Peninsula), although in low numbers, regularly use the Pacific coast during their migration to wintering areas. The fact that most records were in winter suggests that Brown skuas are more coastal during the northward migration and probably use more pelagic routes during their trip back to their breeding grounds. A similar migratory pattern has been observed in the South Polar skua (Kopp et al. 2011).

Other Stercorarius species reported for Chilean waters but not recorded in the present study include the South Polar skua and the Pomarine and Long-tailed jaegers. During their migration trips, all three species use comparatively more oceanic waters than the species observed in this study (Harrison 1988; Jaramillo 2005; Kopp et al. 2011), and this may have hindered their observation within our study area which included mostly coastal waters.

Two species (Brown skua and Parasitic jaeger) showed a strong seasonal presence in the study area and were completely segregated in the time they passed off Valparaiso, reflecting their breeding and migratory habits at opposite sides of the globe. Chilean skuas showed a nearly constant presence in the area throughout the period of study, with lowest abundances during summer when birds are concentrated at their breeding grounds (the few birds we observed were probably non-breeders). Low abundances during autumn and early winter suggest that Chilean skuas use the waters off Valparaiso only as a flyway during their northward migration. During late winter and early spring, however, Chilean skua densities tend to increase (Figure 2a), suggesting that the waters off Valparaiso may serve as a pre-breeding staging area where individuals may forage and gain body condition lost during the energetically demanding southern migration. The Valparaiso Bay supports a large marine productivity derived from upwelled waters from the nearby Curaumilla Point (see Figure 1 for locations) 


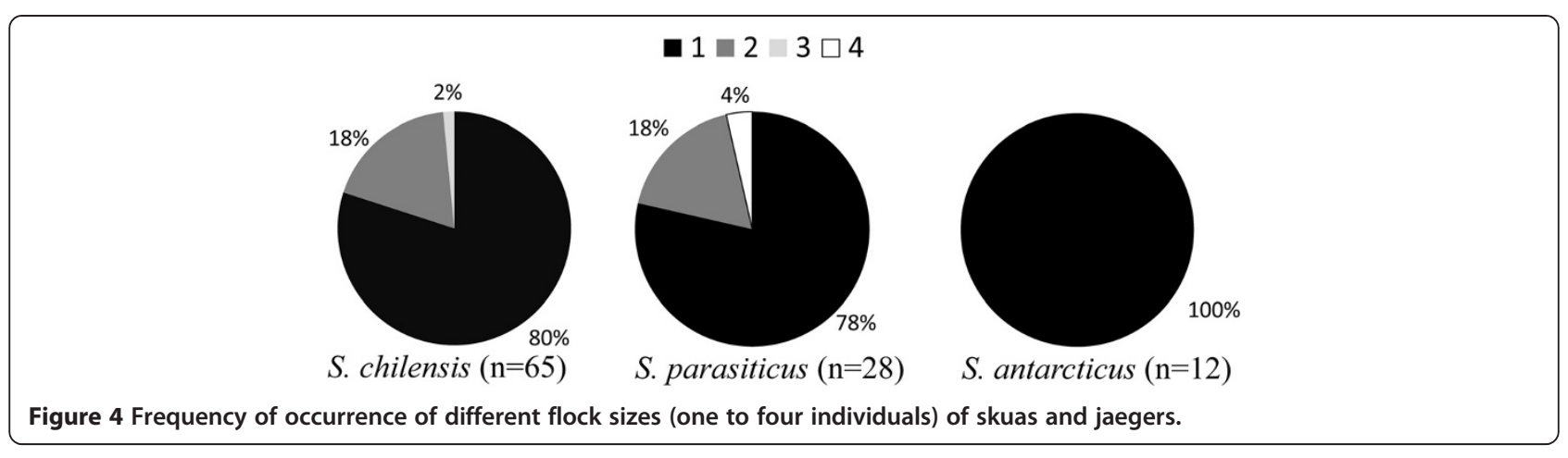

(Sievers and Vega 2000; Silva and Valdenegro 2003; Aiken et al. 2008; Thiel et al. 2007). A similar strategy has been reported for South Polar skuas during their return (spring) migration; individuals stop at terminal staging areas mostly off Peru to take advantage of increased local marine productivity before continuing their trip to breeding areas nearly 3,000 km to the south (Kopp et al. 2011).

The two skua species used similar areas and reached similar distances to the coast, comparatively more offshore. The parasitic jaeger, on the other hand, is mostly coastal in habitat use, which is probably related to host (gulls and terns) distribution, which has also a coastal distribution (Furness 1987a; Arcos 2000).

Parasitic jaegers associated to other seabird species exclusively for kleptoparasitic purposes, which is consistent with their classification as 'specialized kleptoparasites' (Furness

Table 2 Seabird species involved in different behaviors with skuas and jaegers

\begin{tabular}{|c|c|c|}
\hline & $\begin{array}{l}\text { Chilean } \\
\text { skua (56) }\end{array}$ & $\begin{array}{c}\text { Parasitic } \\
\text { jaeger (51) }\end{array}$ \\
\hline Southern fulmar (Fulmarus glacialoides Smith) (48) & K & \\
\hline $\begin{array}{l}\text { Pink-footed shearwater (Puffinus creatopus } \\
\text { Coues) (48) }\end{array}$ & K & \\
\hline Sooty shearwater (Puffinus griseus Gmelin) (43) & $\mathrm{K}, \mathrm{F}$ & \\
\hline $\begin{array}{l}\text { White-chinned petrel (Procellaria aequinoctialis } \\
\text { Linnaeus) (54) }\end{array}$ & $\mathrm{R}$ & \\
\hline Peruvian booby (Sula variegata Tschudi) (74) & K & \\
\hline $\begin{array}{l}\text { Magellanic penguin (Spheniscus magellanicus } \\
\text { Forster) (70) }\end{array}$ & F & \\
\hline $\begin{array}{l}\text { Guanay cormorant (Phalacrocorax bougainvillii } \\
\text { Lesson) (76) }\end{array}$ & $\mathrm{F}$ & \\
\hline Kelp gull (Larus dominicanus Lichtenstein) (58) & $\mathrm{F}$ & \\
\hline Franklin's gull (Larus pipixcan Wagler) (40) & & K \\
\hline Grey gull (Larus modestus Tschudi) (46) & & K \\
\hline Inca tern (Larosterna inca Lesson) (41) & $\mathrm{F}$ & K \\
\hline $\begin{array}{l}\text { Arctic tern (Sterna paradisaea) } \\
\text { Pontoppidan (38) }\end{array}$ & & K \\
\hline $\begin{array}{l}\text { South American tern (Sterna hirundinacea } \\
\text { Lesson) (42) }\end{array}$ & & K \\
\hline
\end{tabular}

In parenthesis are the average bird sizes (body length in $\mathrm{cm}$ ) after Jaramillo (2005). K, kleptoparasitism; F, feeding; R, resting. 1987b). Jaegers chased mostly migratory species such as Franklin's gulls and Arctic terns, all boreal migrants. This is consistent with the observations that jaegers synchronize their migrations with those of their hosts and follow them during their migratory movements (Furness 1987a). However, parasitic jaegers were also able to take advantage of local species such as South American and Inca terns and Grey gulls. Jaegers kleptoparasitized only smaller birds (see Table 2), supporting the idea that size is an important factor influencing host species selection as smaller species are more vulnerable and prone to drop food items after being chased (Furness 1987a; Arcos 2000). Chilean skuas kleptoparasitized on both smaller and larger seabirds (e.g., Peruvian booby) but were also able to engage in multispecies flocks for feeding and resting, in accordance to their classification as 'opportunistic kleptoparasites' (Furness 1987b). Remarkably, Chilean skuas and Parasitic jaegers seem to be almost completely segregated in the species they associate with as only Inca terns were common hosts to both Stercorarius species, although with different purposes (see Table 2). Brown skuas were never seen associated to other species.

Most individuals observed at sea were single birds, suggesting that migratory movements are not in large groups but occur rather in solitary. At least in Parasitic jaegers, this strategy may help individuals maximize host chasing and food retrieval, at least when small hosts are selected (as observed in this study). Larger groups of jaegers may result too conspicuous for the hosts (Furness 1987b) and may be profitable only when attempting to chase a larger host, although this does not necessarily increase the rate of success (Arcos 2000).

We are aware that one sampling per month appears inadequate for inferring abundance patterns for any seabird species, and a higher frequency would be desirable to generate more confident estimates (see Camphuysen et al. 2004). However, our sampling effort has been constant over 7 years, and we consider this likely to provide consistency to our results. Given the extensive migrations these species undertake, future studies should include the use of satellite telemetry to elucidate specific routes used during postbreeding migrations, specific wintering areas, and stopovers. 


\section{Conclusion}

Chilean skuas occur year-round off the Valparaiso Bay while Brown skuas and Parasitic jaegers showed a marked seasonality in their occurrence and abundance. Skuas occur more offshore while jaegers are more coastal and this seems to be related to host distribution. Stercorarius species use this area as a commuting and stopover zone within their extensive migratory flyway along the southeastern Pacific.

\section{Competing interest}

The authors declare that they have no competing interests.

\section{Authors' contributions}

AS conceived the study, participated in its design and coordination, collected the data, and wrote the manuscript. CA contributed to the analysis of data, collected the data and prepared all figures. GL-J performed the statistical analysis. All authors read and approved the final manuscript.

\section{Acknowledgements}

We are grateful to the many on-board observers that helped throughout the years, particularly to M. Bernal, K. Burgos, L. Cabezas, J. C. Hernández, N. Herrera, L. Henríquez, L. Hiriart-Bertrand, G. Iñiguez, R. Norambuena, P. Núñez, J. Parra, I. Salas, D. Toledo, and A. Velasco. The help of the crew of 'Fresia del Carmen' (Andrea, Christian, Jano, 'Keno,' and 'Poroto') was invaluable to our work at sea. We thank two anonymous reviewers for their valuable comments and suggestions to the manuscript. Financial support to this project has been provided by research grants AR-03-05, DI-07-08, DI-48-10, and DI-132-12 from the Vicerrectoria de Investigacion y Doctorado, Universidad Andres Bello (Chile) to A. Simeone.

\section{Author details}

'Departamento de Ecología y Biodiversidad, Facultad de Ecología y Recursos Naturales, Universidad Andres Bello, República 470, Santiago 8370251, Chile. 2 Departamento de Biología Marina, Facultad de Ciencias del Mar, Universidad Católica del Norte, Larrondo 1281, Coquimbo 1781421, Chile. ${ }^{3}$ Centro Estudios Avanzados en Zonas Áridas (CEAZA), La Serena 1781421, Chile.

Received: 22 July 2013 Accepted: 24 March 2014

Published: 15 July 2014

\section{References}

Aiken CM, Castillo M, Navarrete S (2008) A simulation of the Chilean Coastal Current and associated topographic upwelling near Valparaiso, Chile. Cont Shelf Res 28:2371-2381

Arcos JM (2000) Host selection by Arctic skuas Stercorarius parasiticus in the northwestern Mediterranean during spring migration. Ornis Fennica 77:131-135

Braun MJ, Brufield RT (1998) Enigmatic phylogeny of skuas: an alternative hypothesis. Proc R Soc Lond B 265:995-999

Calenge C (2006) The package "adehabitat" for the R software: a tool for the analysis of space and habitat use by animals. Ecol Model 197:516-519

Camphuysen CJ, Garthe S (2004) Recording foraging seabirds at sea: standardised recording and coding of foraging behaviour and multi-species foraging associations. Atlantic Seabirds 6(1):1-32

Camphuysen CJ, Fox T, Leopold M, Petersen IK (2004) Towards a standardized seabirds at sea census techniques in connection with environmental impact assessments for offshore wind farms in the U.K. Final report COWRIE-BAM-022002. Royal Netherlands Institute for Sea Research, Texel

Chu PC, Eisenschenk SK, Zhu ST (2009) Skeletal morphology and the phylogeny of skuas (Aves: Charadriiformes, Stercorariidae). Zool J Linnean Soc 157:612-621

Cohen BL, Baker AJ, Blechschmidt K, Dittmann DL, Furness RW, Gerwin JA, Helbig AJ, De Korte J, Marshall HD, Palma RL, Peter HU, Ramli R, Siebold L, Willcox MS, Wilson RH, Zink RM (1997) Enigmatic phylogeny of skuas (Aves: Stercorariidae). Proc R Soc Lond B 264:181-190

Furness RW (1987a) The skuas. T. \& A. D. Poyser, London

Furness RW (1987b) Kleptoparasitism in seabirds. In: Croxall JP (ed) Seabirds: feeding ecology and role in marine ecosystems. Cambridge University Press, Cambridge, pp 77-100

Garthe S, Hüppop O (1996) Das "seabirds-at-sea" programm. Vogelwelt (Germany) 117:303-305
Garthe S, Hüppop O (1999) Effect of ship speed on seabird counts in areas supporting commercial fisheries. J Field Ornithol 70:28-32

Garthe S, Hüppop O (2000) Aktuelle entwicklungen beim Seabirds-at-Sea-Programm in Deutschland. Vogelwelt (Germany) 121:301-305

Harrison P (1988) Seabirds: an identification guide. Christopher Helm, London

Jaramillo A (2005) Aves de Chile. Lynx Edicions, Barcelona

Kopp M, Peter H-U, Mustafa O, Lisovski S, Ritz MS, Phillips RA, Hahn S (2011) South Polar skuas from a single breeding population overwinter in different oceans though show similar migration patterns. Mar Ecol Prog Ser 435:263-267

Phillips RA, Catry P, Silk JRD, Bearhop S, McGill R, Afanasyev V, Strange IJ (2007) Movements, winter distribution and activity patterns of Falkland and Brown Skuas: insights from loggers and isotopes. Mar Ecol Prog Ser 345:281-291

Phillips RA, Bearhop S, McGill RAR, Dawson DA (2009) Stable isotopes reveal individual variation in migration strategies and habitat preferences in a suite of seabirds during the breeding period. Oecologia 160:795-806

Raimilla V (2012) Primer registro documentado del salteador pardo Stercorarius antarcticus (Lesson, 1831) (Stercorariidae) para las costas del Pacífico Sur desde el Archipiélago Diego Ramírez, sur de Chile. Anales Instituto de la Patagonia (Chile) 40:151-154

Remsen JV, Cadena CD, Jaramillo A, Nores M, Pacheco JF, Pérez-Emán J, Robbins MB, Stiles FG, Stotz DF, Zimmer KJ (2013) A classification of the bird species of South America. American Ornithologists' Union, http://www.museum.lsu.edu/ Remsen/ SACCBaseline.htm. Accessed 22 July 2013

Ritz MS, Millar C, Miller GD, Phillips RA, Ryan P, Sternkopf V, Liebers-Helbig D, Peter H-U (2008) Phylogeography of the southern skua complex - rapid colonization of the southern hemisphere during a glacial period and reticulate evolution. Mol Phylogenet Evol 49:292-303

Schulenberg TS, Stotz DF, Lane DF, O'Neill JP, Parker TA (2010) Aves del Perú. Serie Biodiversidad Corbidi 01, Lima

Sievers H, Vega S (2000) Respuesta físico-química de la bahía de Valparaíso a la surgencia generada en Punta Curaumilla y al fenómeno El Niño. Revista de Biología Marina y Oceanografía (Chile) 35:153-168

Silva N, Valdenegro A (2003) Evolution of an upwelling event off Punta Curaumilla, Valparaíso. Investigaciones Marinas (Chile) 31:73-89

Silverman BW (1986) Density estimation for statistics and data analysis. Chapman and Hall, London

Spear L, Ainley D (2008) The seabird community of the Peru Current, 1980-1995, with comparisons to other eastern boundary currents. Marine Ornithology (South Africa) 36:125-144

Tasker ML, Jones PH, Dixon T, Blake BF (1984) Counting seabirds at sea from ships: a review of the methods employed and suggestions for a standardized approach. Auk 101:567-577

Thiel M, Macaya EC, Acuña E, Arntz WE, Bastias H, Brokordt K, Camus PA, Castilla JC, Castro LR, Cortés M, Dumont CP, Escribano R, Fernandez M, Gajardo JA, Gaymer CF, Gomez I, González AE, González HE, Haye PA, Illanes JE, Iriarte JL, Lancellotti DA, Luna-Jorquera G, Luxoro C, Manriquez PH, Marín V, Muñoz P, Navarrete SA, Perez E, Poulin E et al (2007) The Humboldt Current system of northern and central Chileoceanographic processes, ecological interactions and socioeconomic feedback. Oceanogr Mar Biol 45:195-344

Watson GE (1975) Birds of the Antarctic and Sub-Antarctic. William Byrd Press, Richmond, Virginia

Webb A, Durinck J (1992) Counting birds from ship. In: Komdeur J, Bertelsen J, Cracknell G (eds) Manual for aeroplane and ship surveys of waterfowl and seabirds. IWRB Spec Publ No 19, Slimbridge, pp 24-37

Worton BJ (1989) Kernel methods for estimating the utilization distribution in home-range studies. Ecology 70:164-168

Worton BJ (1995) Using Monte Carlo simulation to evaluate kernel-based home range estimators. J Wildl Manag 59:794-800

Yorio P (2005) Estado poblacional y de conservación de gaviotines y escúas que se reproducen en el litoral marítimo Argentino. Hornero (Argentina) 20:75-93

doi:10.1186/0717-6317-87-6

Cite this article as: Simeone et al:: At-sea abundance and distribution of skuas and jaegers (Charadriiformes: Stercorariidae) at coastal waters off central Chile. Revista Chilena de Historia Natural 2014 87:6. 